
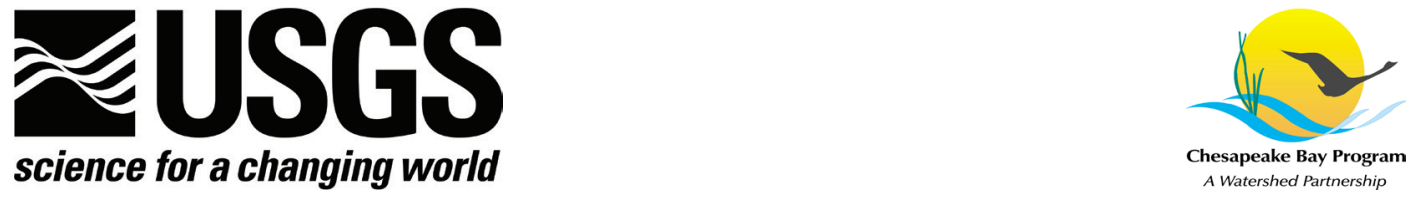

\title{
Proceedings of the Workshop on Alternative Futures: Accounting for Growth in the Chesapeake Bay Watershed
}

Baltimore, Maryland

September 15, 2011

Edited by Peter Claggett and Renee Thompson

Open-File Report 2012-1216 


\section{U.S. Department of the Interior \\ KEN SALAZAR, Secretary \\ U.S. Geological Survey \\ Marcia K. McNutt, Director}

\section{U.S. Geological Survey, Reston, Virginia: 2012}

For more information on the USGS - the Federal source for science about the Earth, its natural and living resources, natural hazards, and the environment—visit http://www.usgs.gov or call 1-888-ASK-USGS

For an overview of USGS information products, including maps, imagery, and publications, visit http://www.usgs.gov/pubprod

To order this and other USGS information products, visit http://store.usgs.gov

Any use of trade, firm, or product names is for descriptive purposes only and does not imply endorsement by the U.S. Government.

The presentations and handouts by non-U.S. Geological Survey (USGS) authors in this volume are published as they were submitted. Presentations and handouts authored entirely by non-USGS authors do not represent the views or position of the USGS or the U.S. Government and are published solely as part of the Proceedings volume.

Although this report is in the public domain, permission must be secured from the individual copyright owners to reproduce any copyrighted material contained within this report.

Suggested citation:

Claggett, Peter, and Thompson, Renee, eds., 2012, Proceedings of the workshop on alternative futures-Accounting for growth in the Chesapeake Bay watershed: U.S. Geological Survey Open-File Report 2012-1216, 29 p., available only at http://pubs.usgs.gov/of/2012/1216. 


\section{Contents}

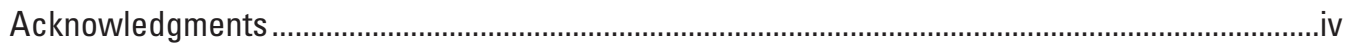

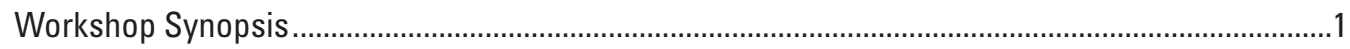

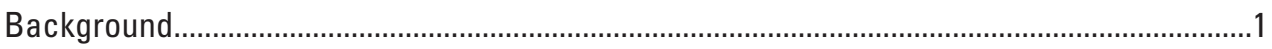

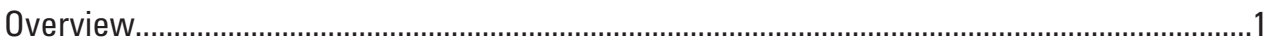

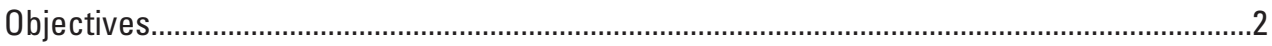

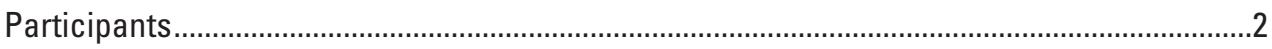

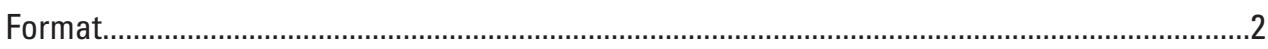

Preliminary Outcomes...................................................................................................... 2

Opening Remarks and Introductions ………….........................................................................

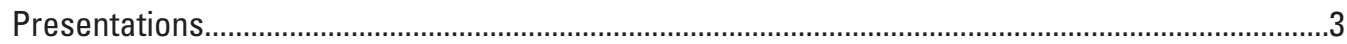

Alternative Futures: Accounting for Growth in the Chesapeake Watershed; Pollution Diets, Offsets and Alternative Futures, Oh My!, Rich Batiuk, Associate Director for Science, EPA Chesapeake Bay Program Office ……………...................................

Planning as a BMP - Steven Stewart, Baltimore County Department of Environmental Protection and Resource Management .......................................................................

Chesapeake Bay Land Change Model: Trend Scenario - Peter Claggett, Research Geographer, USGS Chesapeake Bay Program Office..................................................

Urban Infill: One Potential Alternative Future - Renee Thompson, Geographer, USGS Chesapeake Bay Program Office .........................................................................

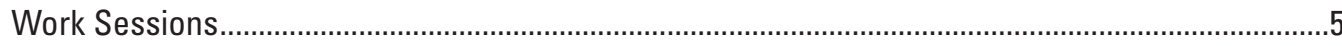

Current and Future Trends (small group discussions) .........................................................

Policies for the Future (small group discussions) .............................................................

Priority Policies (group reports) .........................................................................................

Crafting Alternative Future Scenarios (plenary discussion) ...................................................10

2017 Model Reevaluation Considerations ............................................................................11

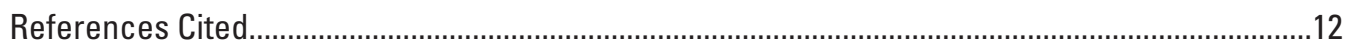

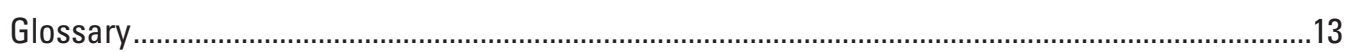

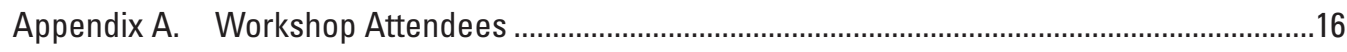

Appendix B. Work Session Notes............................................................................................ 


\section{Acknowledgments}

Workshop organizers Peter Claggett and Renee Thompson would like to acknowledge the numerous partners who were essential in the execution of this event. Workshop steering committee members provided valuable input and direction during the months of planning before the event: they included Jim Baird, American Farmland Trust; Mark Bryer, The Nature Conservancy; and Mike Fritz, U.S. Environmental Protection Agency Chesapeake Bay Program Office. In addition to serving on the workshop steering committee, the above mentioned also were invaluable by serving as group moderators and facilitators along with Anna Stuart Burnett, Chesapeake Research Consortium, Chesapeake Bay Program; David Donato, U.S. Geological Survey; Fred Irani, U.S. Geological Survey; and Kitty Smith, American Farmland Trust. Finally, this workshop would not have been possible without the generous financial sponsorships from the National Center for Smart Growth, The Nature Conservancy, and the American Farmland Trust.
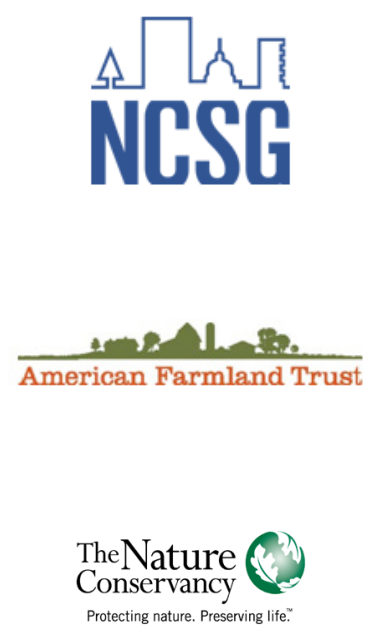


\title{
Proceedings of the Workshop on Alternative Futures: Accounting for Growth in the Chesapeake Bay Watershed
}

\author{
Edited by Peter Claggett and Renee Thompson
}

This workshop was convened by Peter Claggett and Renee Thompson, U.S. Geological Survey Eastern Geographic Science Center, Chesapeake Bay Program Office

September 15, 2011

The workshop was hosted by the U.S. Geological Survey Maryland-Delaware-District of Columbia Water Science Center, Baltimore, Maryland

\section{Workshop Synopsis}

\section{Background}

Between 2010 and 2025 the population within the Chesapeake Bay watershed is expected to increase by approximately 2 million persons (Chesapeake Bay Program, 2012). The increase in population and associated land development will challenge the progress of restoration and protection efforts in the Chesapeake Bay ecosystem. The U.S. Geological Survey (USGS) Chesapeake Bay Program Office (CBPO) is using the Chesapeake Bay Land Change Model and the Community Watershed Model, Phase 5.3.2, to estimate potential future changes in nutrient and sediment loads to the Bay through the year 2025 to inform the development of Phase II Watershed Implementation Plans (WIPs) by States and local jurisdictions in the absence of more detailed local data. The year 2025 is the target for full implementation of all Best Management Practices needed to restore the Bay. The U.S. Environmental Protection Agency (EPA) Total Maximum Daily Load (TMDL) guidance calls for jurisdictions to account for growth in their WIPs (U.S. Environmental Protection Agency, 2010). To assist States and local jurisdictions in anticipating and planning for potential increases in nutrient and sediment loads due to plausible levels of future growth, the CBPO Land Data Team has developed an urban growth trend forecast that simulates the extent and spatial distribution of urban growth for all the Bay watershed counties based on recent land-cover trends and State-reported population projections. Urban growth forecasts will not affect TMDL allocations for the Bay, but jurisdictions may choose to adjust their source sector allocations to accommodate expected growth as long as any expected increases in loads are offset by (1) increasing implementation levels, and (or) (2) decreasing allocations for non-urban source sectors. Future growth scenarios that inform strategies to accommodate potential increases in loads help ensure that implementation and offset strategies are sufficient to address expected increases in the magnitude, source, and location of loads.

\section{Overview}

This workshop provided a forum for identifying and discussing policies and assumptions for use in creating regionally consistent alternative future land-use scenarios. The alternative scenarios will help to inform how planning can potentially be used as a primary Best Management Practice by identifying land- 
use policies and other planning actions that can be taken to minimize future increases in nutrients and sediments associated with the spatial pattern and intensity of land development. The CBPO will run these scenarios through the watershed model to quantify the differences in loadings achieved through implementation of land-use policies and to help assess the uncertainty associated with the current trend forecast. In addition, the outcomes of this workshop can assist jurisdictions in planning for growth with respect to minimizing future increases in nutrient and sediment associated with land development. Ultimately, this workshop was intended to provide jurisdictions with information that can be used to better account for refinement of their WIPs.

\section{Objectives}

The workshop's principle objectives were to develop:

1. A set of alternative future land-use scenarios with supporting policy narratives for the Chesapeake Bay watershed. The alternative future scenarios will be used to evaluate the impact of land-use policies and planning as a water quality Best Management Practice to reduce and minimize future increases in nutrient and sediment loads to streams and the Chesapeake Bay.

2. A list of recommended improvements to the Chesapeake Bay Land Change Model and the Community Watershed Model. The list will be used to help determine what changes should be made to these models to better reflect characteristics of real world planning that are not currently accounted for in the models.

\section{Participants}

Over 45 participants were present at the workshop, representing local, State, and nonprofit organizations from across the Chesapeake Bay watershed. The workshop was geared toward individuals who had expertise and special knowledge related to land-use trends and policies in their jurisdiction. In addition, several individuals representing various local planning agencies were able to join remotely by WebEx and provide input to workshop organizers via e-mail. A complete list of participants can be viewed at the end of this report (appendix A).

\section{Format}

The workshop began with presentations in the morning, followed by individually moderated small group work sessions. The workshop concluded with a group plenary session where collective priorities for alternative future scenarios were discussed.

\section{Preliminary Outcomes}

Following the workshop, the USGS drafted eight alternative future scenarios to reflect the majority of priority policies and issues identified in the workshop. The eight scenarios include: Business-As-Usual, Competition Among Pennsylvania Municipalities, Cooperation Among Pennsylvania Municipalities, Land Conservation, Rural Character, Sustainable Chesapeake, Fifty-Percent Infill/Redevelopment, and Seventyfive Percent Infill/Redevelopment. These scenarios are presented in detail beginning on page 10 and are discussed in a general way throughout the comments in appendix B. 


\title{
Opening Remarks and Introductions
}

Peter Claggett welcomed the participants and reviewed the charge and agenda for the workshop. Participants began the meeting seated in preassigned groups of 7 or 8 , with a moderator assigned to each group. The moderators facilitated introductions within each group and prompted the participants to complete the sentence: "Thinking about water quality, my most important concern about future growth is

."Participants listed lack of adequate funding, "sprawl" type development, lack of coordination between various levels of government, increased runoff associated with urban areas, and lack of modeling capability, among their biggest concerns. The complete list of participant responses can be viewed at the beginning of appendix B.

\section{Presentations}

In preparation for small group discussions later in the day, the participants attended three presentations intended to establish a common knowledge base for modeling land-use change in the context of water quality, crafting future scenarios, and the role of land-use planning in the Bay TMDL. In addition, a presentation on infill/redevelopment as a possible alternative future land-use scenario was presented. A PDF copy of each of the presentations can be accessed by clicking on the hyperlinks that follow each presentation summary below.

\section{Alternative Futures: Accounting for Growth in the Chesapeake Watershed; Pollution Diets, Offsets and Alternative Futures, Oh My!, Rich Batiuk, Associate Director for Science, EPA Chesapeake Bay Program Office}

Mr. Batiuk's presentation provided background for describing the water quality challenges that the Chesapeake Bay faces, the suite of models and tools used for Bay restoration decision making, and the Chesapeake Bay TMDL strategy that has been implemented to reduce pollution in the watershed. Specifically, Mr. Batiuk focused on EPA guidance related to offsets and how jurisdictions will be expected to account for any new pollution loadings to keep the net pollution under the target nutrient and sediment loads. Mr. Batiuk's presentation, as well as handouts related to TMDL and offsets, can be viewed by following the links below:

\section{Presentation}

Pollution Diets, Offsets, and Alternative Futures - Rich Batiuk, EPA

\author{
Handouts \\ Guide for EPA's Evaluation of Phase 1 Watershed Implementation Plans (April 2010) \\ EPA's Chesapeake Bay TMDL Appendix S-Offsets \\ EPA's Chesapeake Bay TMDL Section 10 - Implementation and Adaptive Management
}

\section{Planning as a BMP - Steven Stewart, Baltimore County Department of Environmental Protection and Resource Management}

This presentation was crafted to answer the following questions: (1) What is the role of land-use planning and alternative scenarios in accounting for growth and assessing future impacts to water quality? and (2) How can planning improve water quality? Mr. Stewart's presentation provided an overview of integrated watershed management as a concept. He also described how planning provides a first line of defense 
in protecting water quality by directing growth to urbanized areas, protecting natural resources through resource conservation zoning, and promoting policies that encourage redevelopment and revitalization. Background information describing the history of planning in Baltimore County, Maryland, was presented, from the "Plan for the Valleys" in the 1960s to the creation of the Urban-Rural Demarcation Line, later implementation of Rural Land Preservation Zoning in the 1970s, and a more recent focus on redevelopment and designation of growth areas. The impetus for most of the work on this topic for Baltimore County is the State requirement that all counties include a Water Resource Element (WRE) in their master plan. The WRE requires counties to identify suitable receiving waters and land areas to meet stormwater management needs of existing, proposed, and anticipated future development. The county conducted a comprehensive analysis of future pollution loadings and impervious cover associated with the county's anticipated population growth. Three alternative future growth scenarios were analyzed: (1) "business as usual," where past development trends were assumed to continue into the future; (2) targeting all development within priority funding areas (for example, within the county's Urban-Rural Demarcation Line); and (3) redevelopment, where future growth would take place in areas that were already developed and would be rebuilt with high density and mixed uses. The redevelopment scenario was found to produce the greatest reduction of impervious surfaces while protecting the greatest amount of natural resources.

Alternative Futures: Planning as a BMP - Steven Stewart, Baltimore County, MD

\section{Chesapeake Bay Land Change Model: Trend Scenario - Peter Claggett, Research Geographer, USGS Chesapeake Bay Program Office}

Mr. Claggett's presentation provided an overview of the Chesapeake Bay Land Change Model $(\mathrm{CBLCM})$ and the data it requires. The CBLCM estimates the extent of future development in rural, urban, and suburban lands; estimates the historic and future population and households on sewer and septic systems; and estimates the future conversion of forest and farmland. Mr. Claggett described the Phase 5.3.2 trend scenario for developed land-use: assuming that past trends will be a prologue for the years 20062025, the expected land-use changes associated with that trend are described, as are the expected pollution loading rates associated with that trend. Finally, Mr. Claggett provided a framework for workshop participants to help them understand how to conceptualize and craft alternative future scenarios. His presentation provided a summary slide that was used in later sessions to help participants make the connection between policies designed to influence the location, pattern, and extent of growth and how those policies can be categorized for modeling purposes.

The Chesapeake Bay Land Change Model: Trend Scenario - Peter Claggett, USGS

\section{Urban Infill: One Potential Alternative Future - Renee Thompson, Geographer, USGS Chesapeake Bay Program Office}

Ms. Thompson's presentation focused on the concept of urban infill to illustrate how the water quality impacts of policies that promote and provide an incentive for urban infill can be estimated with the CBLCM. This example was intended to provide a framework for group discussions. Ms. Thompson's presentation provided some additional background as to why it is important to investigate alternative futures, including the concept that there is no guarantee that what will happen in the past will happen in the future (trend), the future is full of uncertainties (such as the economy, weather, and climate), and that scenarios 
help to contribute to "good" science by bounding estimates of the extent of development and the associated impacts on water quality. Ms. Thompson then provided a context for infill, citing recent surveys and studies that provide evidence that consumer demand may be shifting to a preference for communities that offer more amenities in a more dense/compact environment. She presented research conducted in the BaltimorePhiladelphia corridor that outlined a methodology for visualizing (mapping) urban infill on a regional scale using nationally available data. This research required defining the urban area and determining the plausible spatial and temporal location of historic infill at the Census Block Group scale. These data were used as a baseline to determine a plausible historic rate of infill. Once the baseline/historic rate was established, Ms. Thompson described how pollution loading rates could vary if the degree or rate of infill were to be increased or decreased in the future.

Modeling the Impact of Urban Infill Scenarios in the Chesapeake Bay Watershed - Renee Thompson, USGS

\section{Work Sessions}

Much of the afternoon was devoted to obtaining input from participants through small group discussions. Participants remained in their original groups. Each group was comprised of representatives from various States and local planning agencies so that the views expressed were not attributed to specific States or organizations but instead reflected the collective wisdom of the individuals present. The first work session focused on topics related to participants' experiences and observations on current development trends, policies that have influenced those trends, and the general impact those trends have had on water quality. The next session focused on policies for the future: What policies are in place or could be put in place to alter current development trends (with a focus on policies that minimize impacts to water quality)? Each group was asked to prioritize its list of future policies. Finally, the participants were reconvened for a plenary session where they shared their key priorities. The participants used four dot stickers to collectively prioritize the key policies and issues that were identified in the small group sessions. They used this plenary session list to draft eight potential future scenarios for the Chesapeake Bay watershed.

\section{Current and Future Trends (small group discussions)}

Groups in the first work session discussed past development trends and expectations for trends to change over the next decade, keeping in mind the location, pattern, and extent of new development. Workshop organizers envisioned this as a brainstorming session to generate a broad range of responses. The discussions were crafted to be a building block for later discussions, as workshop attendees needed to think about the past in order to understand where growth in the Bay watershed is headed, or where using best management practices, could head in the future. Responses were recorded on flip charts.

\section{The following questions were answered:}

1. What have been the major growth and development trends over the past decade?

2. What is the relationship between water quality and the major growth and development trends?

3. What policies and planning strategies influenced those trends?

4. How do you expect those trends to continue or change over the next decade? 
A compiled list of the group answers can be viewed in appendix B. The following is a summary of responses.

1. What have been the major growth and development trends over the past decade?

Participants noted that while low-density, large-lot residential development has been prevalent, there have been many examples of increased commercial development, improvements to transit corridors, and emerging mixed-use communities. The loss of farmland as a result of development was also noted. The major theme that emerged from this conversation can be summed up in the following comment: "Growth in general has been highly variable. There is growing sophistication in some cities, but rural areas continue to be a 'wild west' - and that is the way they want it. In many rural areas, there may be a lack of understanding or caring about the water quality implications associated with growth."

2. What is the relationship between water quality and the major growth and development trends?

In general, participants noted that the growth and development trends related to "explosive sprawl" and associated increases in impervious surfaces have had a negative impact on water quality. It was, however, noted that there are recent trends related to encouraging new development inside urban growth areas as well as recognized trends that certain urban areas are experiencing an increase in demand for infill and redevelopment projects. An increase in urban development intensity has the ability to take pressure off of surrounding greenfield areas and is presumed to have a positive impact on water quality.

3. What policies and planning strategies influenced those trends?

Participants cited the lack of State and local level policies as affecting many of the trends listed. In addition, one group noted that policies have gone through their own trends. Many counties began downzoning rural areas in the 1980s and 1990s, particularly in agricultural and conservation areas. Later they established urban growth boundaries (UGBs). However, it was noted that State water and wastewater policies continue to influence where and how much development can take place.

4. How do you expect those trends to continue or change over next decade?

Some participants were optimistic regarding the future, and others believed that development trends have had and will continue to have adverse impacts on water quality. Participants noted that economic drivers are more important than environmental drivers in many cases, but jurisdictions are beginning to recognize that if they are going to attract certain residents, including aging and younger residents, they will have to meet diverse consumer demands to ensure competitiveness. Some jurisdictions are now moving toward policies related to increasing density near transit stations, improving community walkability, and establishing economic incentive zones. Other jurisdictions are not amenable to new policies that promote increased densities. Some participants thought that sprawl patterns in some jurisdictions might continue or get worse. In some States the environment is not a driver for planning, but in others, such as Maryland, State environmental regulations do drive planning; for example, the Water Resources Element required in local comprehensive plans. In Virginia, the Chesapeake Bay and water quality are not currently drivers of land-use policies, but air quality regulations do play a role.

\section{Policies for the Future (small group discussions)}

This work session was designed to generate ideas that can be used later to craft alternative future scenarios. Participants were asked to identify policies and assumptions affecting the future location, pattern, and extent of development and associated impacts to water quality. The following topics were discussed and prioritized.

1. In the next 20 years, what changes in the location, pattern, and extent of new growth/development could improve or minimize impacts on water quality? 
2. What potential policies or strategies could be expected to achieve those changes?

3. Prioritize group results. High priority ideas/policies are those where:

- Knowing how the idea/policy will affect water quality from the model's perspective will help you

- The idea/policy has a definable impact on the extent or spatial pattern of development; and

- The idea/policy is realistic or at least plausible.

1. In the next 20 years, what changes in the location, pattern, and extent of new growth/development could improve or minimize impacts on water quality?

The responses to this question largely focused on some of the emerging policies that were alluded to in the previous "Current and Future Trends" work section. Policies focused on directing growth to already urbanized areas and enacting and enforcing stronger growth and environmental standards for development were cited. In addition, the need to improve or establish regional planning organizations and shared infrastructure development was an emerging theme.

2. What potential policies or strategies could be expected to achieve those changes?

The responses to this question generated a diverse and long list of potential policies and strategies aimed at achieving increased density in urban areas and protecting natural resources. The complete list is available in appendix B. Many of the suggestions were aimed at establishing Urban Growth Boundaries or some similarly designated areas for urban growth across the watershed while also establishing policies to exclude areas from development. Examples of exclusion areas include shared land conservation priority areas at the Federal, State, local, and nongovernmental organization (NGO) levels - such as the protection of riparian areas, steep slopes, and other sensitive or high-valued areas. Other suggestions centered on establishing policies that provide incentives for developers to build in appropriate areas, including fast tracking the permitting process and providing density bonuses.

3. Prioritize group results. High-priority items are those where:

- Knowing how the idea/policy will affect water quality from the model's perspective will help you

- The idea/policy has a definable impact on the extent or spatial pattern of development; and

- The idea/policy is realistic or at least plausible.

Each group prioritized its larger list. Below is a complete list of what groups identified as key priorities (in no particular order).

- Enforce or strengthen the antidegradation policies (to prevent high-quality environmental areas from further degradation).

- Cap impervious surfaces and offsets with retrofits or low-impact development.

- Target areas closer (distance/proximity) to the Bay. Set policies that are consistent with impact to the Bay. Areas that have the highest impact on the Bay should be targeted. For example, what if there was a "critical area" law, similar to that in Maryland, across the whole watershed? What impact would that have?

- Establish a residential designation authority (as per EPA Region 1) - requiring National Pollutant Discharge Elimination System (NPDES) permits for certain permitting. 
- Initiate stronger State planning authority and involvement in lower jurisdiction requirements.

- Provide incentives for urban redevelopment and infill. Remove existing impediments to building in urban areas and streamline the process for builders; for example, streamline the permitting process, provide tax breaks, provide infrastructure rather than requiring the developer to provide the infrastructure and then back charge.

- Establish designated growth areas to direct new development to existing urban areas and enforce development restrictions with local authorities, including but not limited to restricting water and sewer services to areas within the designated growth areas.

- Establish urban canopy threshold goals.

- Require no net loss of forest lands.

- Explicitly incorporate water quality considerations (similar to the WRE in Maryland) into all development policies (such as for transportation and growth) at all levels (Federal transportation policy, State permitting policies, and county zoning).

- Develop wastewater management plans at all levels of government.

- Resolve inconsistencies in Federal, State, and local policies that address BMPs and building codes, for example.

- Develop multi-level identification for no-development areas (exclusion and avoidance zones). Policies could include, but not be limited to:

$\circ$ Incentive/disincentive for offsets

$\circ$ Directed land acquisition

- Use green infrastructure planning from State and local governments and replicate antidegradation clauses

$\circ$ Growth focused across jurisdictions

- Address regional leakage (uncoordinated planning across municipalities that allows for unfavorable development patterns to move a short distance to adjacent municipalities with lower/different standards) around metro areas and consider more regional planning, including policies, revenue sharing, tax incentives.

- Coordinate infrastructure investment - regional multiple separate storm sewer systems (MS4s).

- Foster commitment and legislation for growing more compactly.

- Increase the value for urban attraction with coordinated transit policies and investment in secondary roads in growth appropriate areas.

- Include economic analysis in future growth areas.

- Collect and integrate effects (from local data) rather than relying on State data. Local data, in some cases, could be more detailed with regard to practices like urban forestry, transfer of development right zones, and direct land acquisition at the county level.

- Address the perception that development is "better than" agriculture from a water quality modeling perspective. 
- Direct a higher proportion of growth (and water quality impact) to designated growth areas.

- Conduct capacity analyses to understand the difference between existing zoning and existing development in growth areas and improve the understanding of the ability for existing urban areas to accommodate new growth.

- Include additional considerations in the exclusion area Alternative Future scenario, including additional sources for an areas's drinking water supply and stream buffers of 1,000 feet for critical areas.

- Analyze growth on major transit corridors.

- For all agricultural land - run current scenarios for growth areas showing 100 percent and growth areas showing 0 (to see how much loss - measure offset capacity).

- Analyze greenways.

- Assume equal distribution of population across a local government area and different development patterns.

- Assume no new "sprawl” type development - that is, development of major subdivisions on greenfield sites.

\section{Priority Policies (group reports)}

Each group reported on their top policy developed in the previous session. During the break, each participant was given four stickers to place next to their priority policies from the previous session. Participants were instructed that the stickers could be used individually or on one priority to add emphasis. The following is a list of the results in order of most votes. The number of votes for each policy is noted in parentheses "()".

- Simulating exclusion/avoidance zones (wetlands, floodplains, green infrastructure) - offsets, coordinated acquisition (20)

- Simulating pollutant load reduction benefits from land preservation (marginal farmland, random preservation) (20)

- Provide incentives for urban infill and redevelopment (tax breaks, back charges, permit acceleration, demonstration projects, improve zoning so it is more difficult to bypass) (15)

- Account for absorption capacity in scenarios (10-year bubble) (the accounting used homes, approved lots, vacancy) (11)

- Zoning coupled with a clean urban-rural demarcation line (different percentages of growth in urban area) (10)

- Municipal competition versus cooperation scenario (9)

- Uniform antidegradation of impervious surface capacity to generate offsets (8)

- Cluster community growth where transportation and infrastructure exists (5)

- Amenity attraction (mixed use, Transit Oriented Development (TOD), walkability) (5)

- Higher standards for stormwater BMPs (5)

- Stronger State planning and oversight (4) 
- Impact of loss of agricultural lands on offset capacity (farmland preservation) (3)

- Strict forested riparian buffer requirements (100 to 1,000 feet) (2)

- Water supply and treatment, road and school investments to attract growth (2)

- Coordinated urban growth boundary across jurisdictions (1)

- Regional Transfer of Development Rights (TDRs) to provide an incentive for urban development and redevelopment $(0)$

\section{Crafting Alternative Future Scenarios (plenary discussion)}

Workshop organizers facilitated a brief discussion on how to cluster the list of priority policies into groups based on similarities in their presumed impacts on the location, pattern, and extent of new development or other commonalities. Due to lack of time, the workshop organizers offered to synthesize the priority policies into a set of alternative future scenarios and solicit feedback from the participants via e-mail on the draft set of scenarios.

The USGS attempted to synthesize the workshop information into a set of cohesive and logical narratives. The initial scenarios were circulated for review by the workshop participants and revised by USGS staff of the Chesapeake Bay Program to address participants' comments and concerns. The following represent the final set of scenarios that will be simulated in the spring of 2012 to evaluate the impact of priority policies on nutrient and sediment loads to the Chesapeake Bay and to inform State offset strategies.

\section{Scenarios 1a and 1b. Business As Usual (revised "Trend" scenario)}

- Scenario 1a will update the current "Trend" scenario using local information on zoning and updated regional data. Local zoning data will be collected where they exist and generalized to serve as a constraint on new growth. County-level population projections and the extent of public/protected lands will be updated. Data from the American Community Survey will be used to estimate vacant housing stock and to determine the amount of future growth that can be accommodated without triggering new construction. Land-cover and housing trends from 2001 to 2005 will be weighted relative to 1984 to 2001 trends to indirectly represent the influence of recent land-use policies and trends.

- Scenario 1b - Pennsylvania highlights the effects of growth management to direct growth to areas that have the infrastructure and capacity to best accommodate it. Municipality boundaries will be used as an interim unit of analysis for allocating growth from the county to the landscape level. This scenario includes all of the assumptions and updates in Scenario 1a, but growth is allocated from counties to municipalities based on the relative capacity of each municipality to accommodate the growth. This scenario assumes that municipalities share resources so that no municipality bears all of the costs of development and the benefits are shared.

\section{Scenario 2. Land Conservation}

This scenario will focus on modeling the effects of policies intended to protect high-valued ecological/ agricultural lands from future development. A variety of spatially explicit land conservation priority maps have been developed by Federal, State, and local governments and NGOs in the Chesapeake Bay watershed. Examples include Maryland and Delaware's Green Infrastructure and Virginia's Conservation Lands Needs Assessment. Similar efforts are underway in West Virginia and Pennsylvania. The working assumption behind this scenario is that all land considered a priority for land conservation/preservation (that is, all priority lands on each State's Green Infrastructure map and all farms on prime soils) will be protected from future development. Future development will be concentrated in the remaining unprotected and undeveloped portions of each county. 


\section{Scenario 3. Rural Character}

Scenario 3 will focus on managing the density of future development in urban, suburban, and rural areas to preserve the rural character of the landscape in the watershed. To define urban, suburban, and rural areas, the USGS will use State or local generalized zoning information where available and estimate the location and extent of urban, suburban, and rural areas using U.S. Census Bureau and land-cover data where local information is unavailable. Within each of these areas, it is assumed that future development densities are managed to limit the conversion of forestland and farmland to new development. Allowable densities in urban and suburban areas will be increased above current levels and the minimum allowable densities in rural areas will range from 1 housing unit per 5 acres in areas adjacent to suburban/urban areas to 1 unit per 20 acres in more distant rural areas.

\section{Scenario 4. Sustainable Chesapeake Bay Watershed}

Scenario 4 combines all of the elements of Scenarios 2 and 3 with aggressive (that is, assumed effective) policies to prevent future development within 300 feet of all streams, shorelines, and wetlands. Scenario 4 will likely produce the lowest levels of new, greenfield development in the watershed.

\section{Scenarios 5a and 5b. Infill and Redevelopment}

These two scenarios will examine the effect of directing a large portion of future growth and development within existing urban areas. Any growth outside of urban areas will be simulated according to Scenario 1a, "Business As Usual." To define the urban and infill areas, the USGS will use local urban-growth boundaries where available (for example, the Priority Funding Areas and the Baltimore Urban Rural Demarcation Line (URDL) in Maryland) and estimate the location and extent of pseudo-urban growth boundaries using U.S. Census Bureau and land-cover data where local information is unavailable.

- Scenario 5a will represent directing 75 percent of future growth and development within urban areas. All policies, incentives, and disincentives designed to concentrate density near transit stations and in other areas with sufficient infrastructure to support it are assumed to be highly effective. This scenario will represent the best-case alternative for infill.

- Scenario 5b will represent a scaled-back version of Scenario 5a, where only 50 percent of future growth and development is directed to urban areas. The same sets of policies and assumptions supporting Scenario 5a are applied to Scenario 5b; they are just assumed to be less restrictive.

\section{Model Reevaluation Considerations}

While this workshop was focused on developing alternative future scenarios that can be modeled within the current Chesapeake Bay Land Change Model framework, it was recognized by workshop planners and participants that the process of modeling is never perfect and there is always room for improvement. With that in mind, participants were asked to identify improvements that should be considered in future versions of the Chesapeake Bay Land Change Model and Community Watershed Model. The following is a list of suggested improvements:

- Use "local" data in modeling; for example, insert high-resolution land-use data in places where the data are available.

- Develop criteria to allow acceptance of locally derived data.

- Understand and reflect differences in the rate of rural versus suburban sprawl.

- Clarify differences between agricultural versus urban loading rates. 
- Credit nutrient and sediment reductions associated with land preservation and the protection of healthy streams.

- Add an economic component.

\section{References Cited}

Chesapeake Bay Program, 2012, Population Growth, Accessed October 20, 2011 from http://www.chesapeakebay. net/issues/issue/population_growth\#inline

U.S. Environmental Protection Agency, 2006, Protecting water resources with higher-density development: U.S. Environmental Protection Agency report no. 231R06001.

U.S. Environmental Protection Agency, 2010, Chesapeake Bay TMDL: U.S. Environmental Protection Agency Region 3 (Mid-Atlantic) Web page at http://www.epa.gov/reg3wapd/tmdl/ChesapeakeBay/tmdlexec.html. 


\section{Glossary}

BMP - Best Management Practice. A method or technique found to be effective for achieving an objective (such as reducing sediment and nutrient pollution).

CBPO - Chesapeake Bay Program Office. The Chesapeake Bay Program is a Federal and State partnership established in 1983 to coordinate the restoration of the Chesapeake Bay and its watershed. Chesapeake Bay Program partners include the States of Delaware, Maryland, New York, Pennsylvania, Virginia, and West Virginia; the District of Columbia; the Chesapeake Bay Commission, a tri-state legislative body; the U.S. Environmental Protection Agency, and a variety of other Federal agencies, advisory groups, and academic institutions (http://www.epa.gov/region3/chesapeake/).

CBLCM - Chesapeake Bay Land-Change Model. The Chesapeake Bay Land-Change Model was developed by the U.S. Geological Survey for analyzing the effects of future population growth on urban landuse change and change population growth on sewer and septic systems in the Chesapeake Bay watershed.

EPA - U.S. Environmental Protection Agency.

ESD - Environmental Site Design. ESD involves measures to preserve natural resources, minimize impervious surfaces, and implement small-scale structural techniques and landscape designs that replicate the natural pre-development hydrology characteristics of a site.

GIS - Geographic Information Systems. An integrated collection of computer software and data used to view and manage information about geographic places, analyze spatial relationships, and model spatial processes. A GIS provides a framework for gathering and organizing spatial data and related information so that it can be displayed and analyzed (http://wiki.gis.com/wiki/index.php/GIS_Glossary/G).

LID - Low Impact Development. Similar to ESD, Low Impact Development is a comprehensive land planning and engineering design approach with a goal of maintaining and enhancing the pre-development hydrologic regime of urban and developing watersheds (http://www.lowimpactdevelopment.org/).

MALPF - Maryland Agricultural Land Preservation Foundation, established by the Maryland General Assembly in 1977, is part of the Maryland Department of Agriculture. The Foundation purchases agricultural preservation easements that forever restrict development on prime farmland and woodland (http://www.malpf.info/).

MPO - Metropolitan Planning Organization. A Metropolitan Planning Organization is a group of representatives from local governments that work together on regional transportation planning. By working together, MPOs strive to achieve consensus on projects between different levels of government and across jurisdictions (http://www.baltometro.org/transportation-planning/functions-of-an-mpo).

MS4s - Municipal Separate Storm Sewer Systems. An engineered collection or conveyance system for transporting stormwater runoff, generally found in developed areas and owned by public entities.

NGO - Non-Governmental Organization. An organization that is not part of government and is a not forprofit business. 
NPDES - National Pollutant Discharge Elimination System. A permit program authorized by the Clean Water Act to control water pollution by regulating point sources of pollution that discharge into waters of the United States (http://cfpub.epa.gov/npdes/).

PFA - Priority Funding Area. Maryland-specific acronym referring to areas designated by local governments for State investments in growth and development. PFAs were authorized in 1997 legislation (http://www.mdp.state.md.us/OurProducts/pfamap.shtml).

TAZ - Traffic Analysis Zone - The unit of geography most commonly used in transportation planning models, generally cartographic boundary files containing transportation data related to commuter patterns and traffic.

TMDL - Total Maximum Daily Load. A TMDL is a calculation of the maximum amount of a pollutant that a water body can receive and still safely meet water quality standards. A TMDL is required for all waters that do not meet water quality standards and that are listed as "impaired" in accordance with section 303(d) of the Clean Water Act.

TOD - Transit Oriented Development. Development associated with fixed rail transit stations or other major public transportation hubs that focuses on creating compact, mixed-use, walkable communities usually within $1 / 4$ to $1 / 2$ mile of a transit station.

TDR - Transfer of Development Rights. Transfer of development rights refers to a method for protecting land by transferring the "rights to develop" the land from a sending area to a receiving area. Transferring development rights allows for increased development densities in receiving areas while restricting development in sending areas.

UGB - Urban Growth Boundary. A regional boundary designating higher density development within the boundary and lower density development outside the boundary.

URDL - Urban Rural Demarcation Line. The URDL is an urban growth boundary that applies specifically to Baltimore County, Maryland, where it was established in 1967 to designate areas that would receive public water and sewer infrastructure and therefore accommodate urban residential, commercial, and employment development (adapted from http://www.baltimorecountymd.gov/Agencies/planning/ masterplanning/smartgrowth.html).

USGS - U.S. Geological Survey.

VMT - Vehicle Miles Traveled. An indicator of motor vehicle travel intensity that is expressed as the total miles driven by all vehicles within a given time period and area. Often, VMT is expressed as a per capita measure for a specific geographic region. Higher values are associated with more "sprawling" geographies.

WIP - Watershed Implementation Plan. EPA requires the Bay watershed States and the District of Columbia to develop Watershed Implementation Plans that provide adequate "reasonable assurance" that the jurisdictions can and will achieve the nutrient and sediment reductions necessary to comply with the TMDL (http://www.mde.state.md.us/PROGRAMS/WATER/TMDL/CHESAPEAKEBAYTMDL/Pages/ programs/waterprograms/tmdl/cb_tmdl/index.aspx). 
WRE - Water Resources Element. A required element of County comprehensive plans in Maryland that assesses and ensures that water supplies, water treatment, and stormwater controls are sufficient to meet the needs of the current and future population. The WRE was mandated in Maryland through House Bill 1141 in 2006 (http://www.mdp.state.md.us/OurWork/WaterResources.shtml). 


\section{Appendix A. Workshop Attendees}

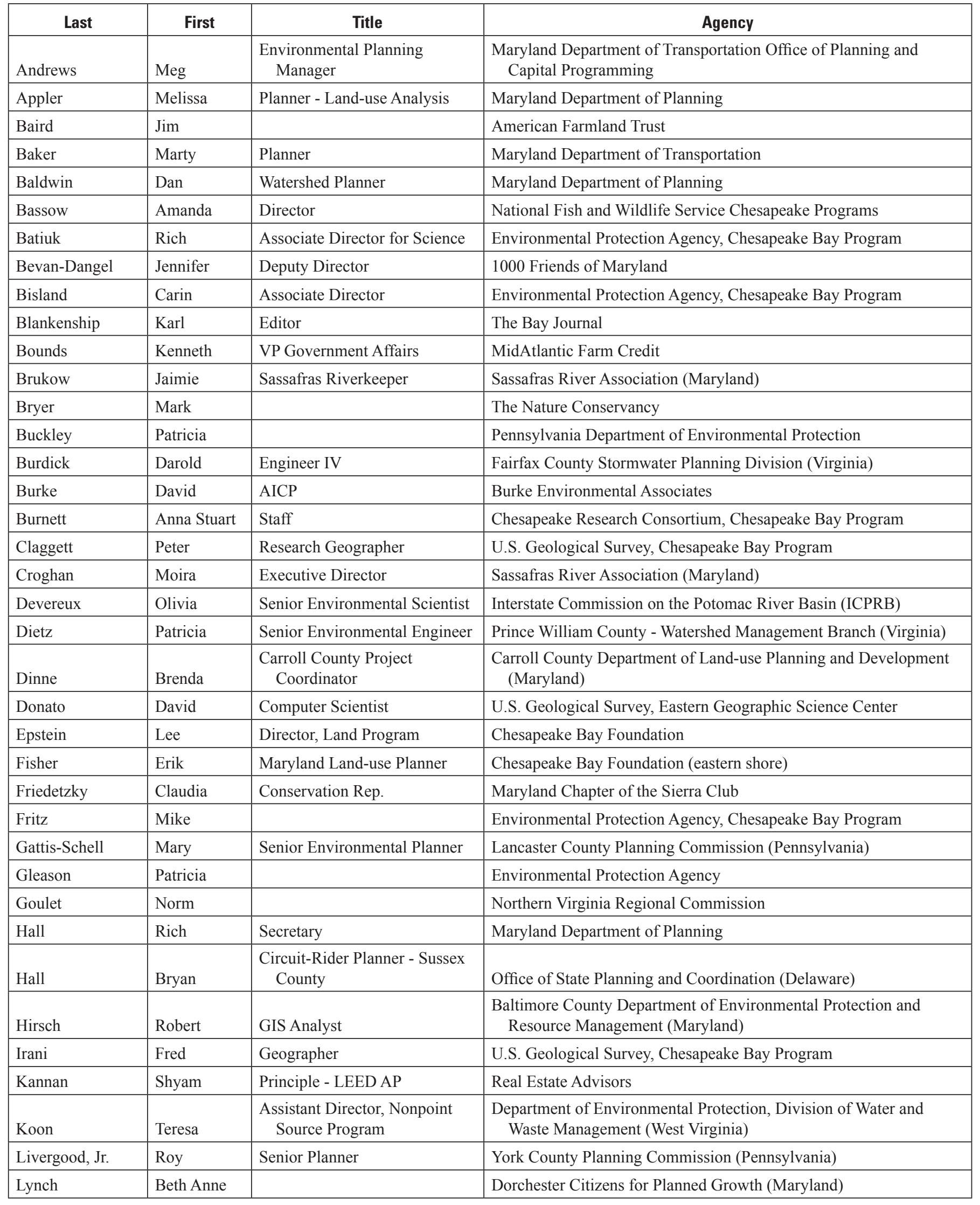




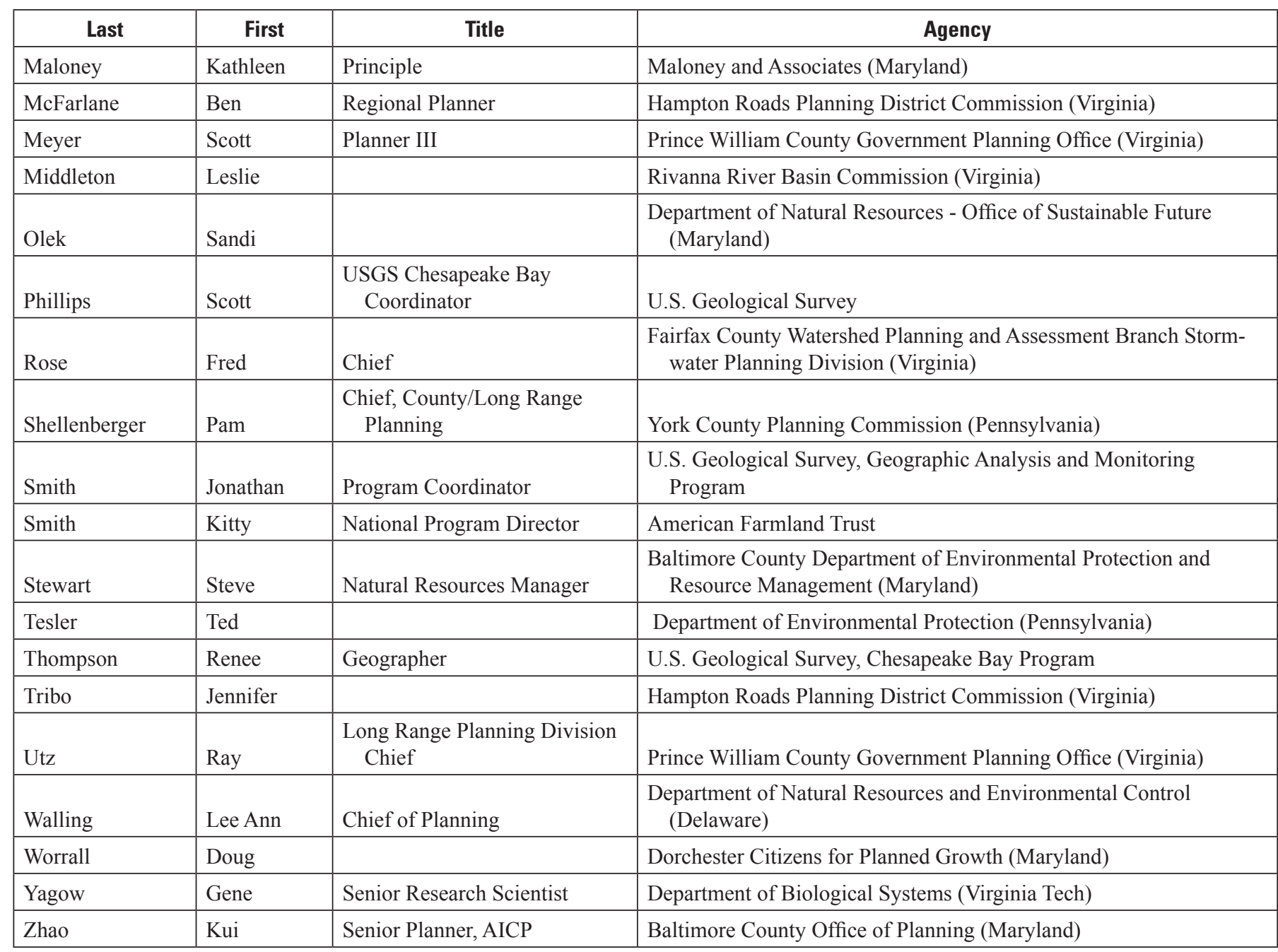




\section{Appendix B. Work Session Notes}

When thinking about water quality, my most important concern about future growth is

- Accommodate for growth and climate change.

- Protect forestland.

- Protect healthy ecosystems.

- Include uncertainty of impacts on current and future infrastructure and the environment.

- Address the impact of chemicals and pharmaceuticals.

- Growth planning will be overly dependent on technology, addressing onsite impact mitigation only and not paying attention to broader impacts and issues.

- Changes to zoning are very difficult.

- Induced impacts are not modeled adequately.

- Urban BMPs carry significant risk of failure and maintenance cost.

- Low-density development is difficult to regulate for water quality.

- There are many data limitations on modeling.

- The continued loss of "healthy watersheds" is not adequately addressed.

- Analysis is underfunded.

- Inform and enable the political environment.

- Financial constraints.

- Greater regulation needed in land-use.

- Mechanism currently in place for offset will not work.

- Conversion from agriculture to low-density development looks better on paper (better for water quality) to uninformed planners and managers.

- In areas of the watershed where there are multiple municipalities and counties it is difficult to track or even consider at all.

- Wastewater treatment: Septic and Sewer.

- Urban stormwater runoff.

- Water availability (potable).

- The mindset that economic development and environmental protection are mutually exclusive. 
- Lack of control over septic systems.

- How to reconcile property rights with public interests.

- Buildout in urban areas will require infill and generally these lots will not have stormwater management built into them.

- Best management practices focus on agriculture and wastewater treatment plants and less on parking lots, roads, and lawns - but these sources also need to be addressed.

- Sprawl.

- Land-use regulations intended to improve water quality could have unintended consequences by sending development elsewhere.

- There is a major management challenge for local governments in that some rural counties have new power (in Pennsylvania, for example).

- Preserving scenic waterways and recreational use with traditional uses (fishing).

- Business cycle impacts on consistency of policy application.

- Missing landscape-scale solutions/strategies as opposed to hyper focus on local BMPs.

- Not addressing urban growth and toxic contaminants and impacts to fish and wildlife.

- Socio-political concern - many officials/citizens still don't understand land-use/water quality connections.

- Cost of BMP's is very high - land-use is not getting enough attention; could be more cost effective.

- Marketing - how do you sell?

- Implementations - how does it get done?

- Accountability - how do we know planning works? How will it be integrated into the model?

- The focus is on 2017-2025, but what happens in 2026 and beyond? What is the plan?

- How do we build a framework into the TMDL process and planning that will adapt to future landuses and link to policy?

- How does the model integrate local economies and demographics?

- How do we integrate TMDL into other socio-economic priorities, including:

- Flood response - floodplain development removal/stormwater BMP's (catalyze action for infrastructure improvement and thereby improve water quality) (co-benefits and damage avoidance).

$\circ$ Housing.

o Climate adaptation. 


\section{Current and Future Trends: Small Group Discussions}

Some groups answered the Current Trends section questions as a group of related questions. Their answers are summarized in the following table.

\begin{tabular}{|c|l|l|}
\hline $\begin{array}{c}\text { What have been the major growth and } \\
\text { development trends in the last decade? }\end{array}$ & \multicolumn{1}{|c|}{$\begin{array}{c}\text { What policies or planning strategies } \\
\text { influenced those trends? }\end{array}$} & What have been the impacts on water quality? \\
\hline $\begin{array}{c}\text { Boom-bust, lot size increasing while } \\
\text { housing size has decreased }\end{array}$ & Policy deficits & Negative \\
\hline $\begin{array}{c}\text { Influence of gasoline price on suburban pref- } \\
\text { erence - some are moving closer to jobs }\end{array}$ & National energy policy and taxes & Positive \\
\hline Increasing market for green redevelopment & More policies needed to encourage this & Positive \\
\hline Inertia to greenfield subdivision paradigm & Government desire for tax base growth & Negative \\
\hline $\begin{array}{c}\text { Some counties including Montgomery and } \\
\text { Baltimore Counties in Maryland have } \\
\text { shown resilience to the "boom and bust" }\end{array}$ & Planning & Positive \\
\hline $\begin{array}{c}\text { Explosive sprawl with impervious sur- } \\
\text { face and only gray infrastructure for } \\
\text { stormwater }\end{array}$ & Lack of policy & Adverse ecological effects, increased runoff, \\
increased burden on streams \\
\hline $\begin{array}{c}\text { Mncreased per capita land-use } \\
\text { of greenfield, redevelopment, and infill, } \\
\text { for example (may be related to economic } \\
\text { conditions) }\end{array}$ & More policies needed to encourage this & Positive \\
\hline
\end{tabular}

\section{What have been the major growth and development trends in the last decade?}

- There has been some urban area redevelopment and more transit and commercial areas are emerging.

- The Dulles corridor has intensified in terms of development.

- Tyson's Corner (in Virginia) is moving toward more mixed use.

- There are more prominent neighborhoods, and the new commercial areas are having some attraction.

- There has been some revitalization in urban areas with greater capital interest in sidewalks and benches (walkability improving).

- Population has doubled in some closer suburbs (Fairfax County, Va.) and are approaching "full buildout." This will force infill and redevelopment and thereby reduce loads.

- In urban areas, there has been more growth, but there has also been more growth in exurban areas in an effort to provide cheaper and larger housing. A lot of this exurban growth has taken place outside designated growth areas.

- In West Virginia there has been large lot, large home development on agricultural lands.

- Transportation infrastructure is not keeping pace with increasing traffic.

- In areas outside of the urban core, there is generally a lack of a good transit system.

- There has been a trend of commercial sprawl - pad site development.

- Built out areas are not expanding; some areas (such as Newport News, Va.) are purchasing industrial land and working to naturalize flood plains. 
- Virginia Beach has undergone a great deal of growth; it has doubled in the last 2 to 3 decades, but there have been efforts to create greener building "green line" service districts and strategic growth areas as well as updating wastewater treatment plants.

- Growth in general has been highly variable; there is growing sophistication in some cities but rural areas continue to be a "wild west" - and that is the way they want it. There may be a lack of understanding or caring about the water quality implications associated with growth.

- Some areas such as the Susquehanna Valley in Pennsylvania have experienced a decrease in population but still continue to "sprawl."

- Developing counties believe development pays for itself.

- In Delaware, there is transition; the agricultural business plans to sell marginal land and increase production on higher yielding lands. Agricultural areas are driving land-use change. Generally the development in Delaware has taken the form of a "strip mall" or "sprawl" pattern characterized by low density on 1-5 acres. Income seems to have an effect on the type of sprawl that is; land values and available acreage in urban corridors (for example, Baltimore-Washington) constrain large lot suburban development - this is not the case in more rural counties.

- West Virginia has experienced second-home development and has little to no zoning.

- Urbanized areas such as Washington, D.C., are beginning to see success with infill and redevelopment but areas in Northern Virginia, such as Loudoun County, don't seem to be buying in. Different developers have different perspectives.

- Some rural areas are fighting development and aligning around agricultural and environmental preservation.

- Initially, farmland preservation programs centered priorities on soils, but are beginning to include proximity and making connections to sustainability and local small-scale agricultural operations.

- Lancaster County, Pa., is an exception to other rural areas in that the county has created a Route 30 growth zone and are poised to take advantage of emerging tools to manage growth.

- A representative from a more rural to exurban county noted that the county had established an Urban Growth Boundary (UGB) and that 90 percent of new development since the establishment of that boundary had in fact taken place within this UGB. In general, however, the nature of this development would not be considered dense but rather more suburban, like with $1 / 4$ acre lots. All the development is on sewer.

- Development on marginal farmland is becoming fragmented with large lot development.

- Some of the participants took the opportunity to note the obstacles and issues they are facing with respect to growth; the issues included:

- Lack of capacity within designated growth areas to meet projected growth (sewer and water capacity).

- There are conflicts between State planning agencies directing where growth should go and the State environmental agencies that set limits on sewer and wastewater capacity. 
- Department of Health upgrading of septic systems allows development where it otherwise could not have gone.

○ There are some loopholes within the existing zoning that have allowed more development in rural areas than would normally be allowed (family subdivisions, for example).

- Automobile-dependent communities, McMansions (trend interrupted), immigration, local opposition to public transportation, opposition to subdivision interconnectivity, out migration seeking lower housing prices, condos changing to rentals, big box retail stores, younger generation moving in is more environmentally conscious. More environmental activism, more stringent environmental regulations.

- Increasing gasoline prices but greater commute times.

\section{What is the relationship between water quality and the major growth and development trends?}

- Continued degradation of local streams.

- Resource protection areas (for example, resulting from the critical area law in Maryland) have made some streams better.

- There is a disconnect between the update of comprehensive plans and ordinances being updated.

- Generally, the trends have been bad for water quality.

- There is a technology gap in that the technology doesn't exist to address the problem and systems that are in place are often not properly maintained.

- Urban BMP's are not serving their intended purpose.

- Downzoning strategies aimed at protection of water quality and stream buffers have protected/ improved water quality.

- Awareness, enforcement, controls on septic systems are lacking (negative water quality impact).

- Development causes damage to water quality, and regulating development should help water quality. It is also important to remember agriculture and not just development.

- Local laws and customs result in variation in the government's ability to affect activities impacting water quality. The Clean Air Act is more of a driving force for change at this point.

- There is also anti-government sentiment and some feel that there is already too much government regulation infringement on local policies.

\section{What policies or planning strategies influenced those trends?}

- Zoning - strong rural and flexible urban zoning.

- Infrastructure extensions.

- Increased political will to collaborate across the Chesapeake Bay watershed and buy-in from local governments into the bigger picture in terms of managing growth.

- Little or no water quality consideration in planning for development - but this is slowly changing.

- Failed attempt at growth containment/lack of political will. 
- Ignoring infrastructure needs/economic conditions.

- Improved low-impact development and environmental site design.

- One group noted that policies have gone through their own trends; many counties began in the 1980s and 1990s with downzoning. This policy makes the ability to develop more restrictive in agricultural and conservation areas. Later they established UGBs and are now moving toward policies related to increasing density near transit stations, improving community walkability, and establishing economic incentive zones. It was noted, however, that State water and wastewater policies continue to influence where and how much development can take place.

\section{How do you expect those trends to continue or change over the next decade?}

- Trends will continue unless we have education and political will for the big picture.

- What is the goal? It is not possible to reforest or return to the undeveloped state so there needs to be focus on local watershed health and protection.

- State policies as well as lack of local leadership or buy in will continue to be a challenge.

- Development trends will not change in the future due to the State and local political climate being adverse to change. In addition, some even thought it may get worse.

- There is beginning to be more of a focus on the qualitative aspects of development, such as Transit Oriented Development (TOD), variety of development forms (mixed use).

- Economic drivers are more important than environmental drivers in many cases, but jurisdictions are beginning to recognize that if they are going to attract certain residents they will have to meet diverse consumer demand to assure competitiveness.

- Consumer demand is growing for different housing types, walkable areas, parks, and other qualitative aspects of "smart growth" communities.

- In some States, the environment is not a driver for planning but in others, such as Maryland, State environmental regulations do drive planning, such as the Water Resources Element required in local comprehensive plans. In other States, such as Virginia, the Chesapeake Bay and water quality currently are not drivers but air quality regulations do play a role.

- The increasing dependence on the automobile and the decreasing size of the government in a tight budget climate, while also increasing government regulation.

- Economically stagnant middle class/working class (income will affect home size and vehicle miles travelled (VMT).

- Immigration is on the rise, and these are close knit communities.

- Drinking water use drives public interest locally.

- Market will continue to favor infill.

- Gasoline influence: the rising price of gasoline will increase infill demand.

- "Leapfrog" pattern growth will continue - infrastructure will be influenced.

- Continued loss of viable agricultural land. 


\section{Policies for the Future}

In the next 20 years, what changes in the location, pattern, and extent of new growth/development could improve or minimize impacts to water quality?

- Target areas closer (distance/proximity) to the Bay. Set policies that are consistent with impact to the Bay. Areas that have the highest impact on the Bay should be targeted. For example, what if there was a critical area law, similar to the law in Maryland, across the whole watershed. What impact would that have?

- Cut land consumption by half.

- Cap impervious surface and offset with retrofits or low impact development.

- No net loss of forest.

- Increase urban reforestation.

- Provide incentives for green construction.

- Compensate land owners for loss of development rights.

- Protect healthy watershed.

- Enforce or strengthen the antidegradation policies.

- Prioritize growth in different sectors (environment, transportation, business, infrastructure) - in addition to population.

- Provide access for rural areas without planning departments: establish regional planning agencies.

- Do a better job of identifying the sources of pollution beyond just land-use.

- Address "leakage" (uncoordinated planning across municipalities allows for unfavorable development patterns to move a short distance to adjacent municipalities with lower/different standards) between jurisdictions, especially in metro areas. There is a lack of regional coordination between the District of Columbia and inner suburbs and the outer suburbs - there needs to be more regional planning.

- Address the counties that do not want to "grow" a lot.

- Shared infrastructure development.

- MS4 permits could provide an impetus for greater regional coordination.

- Combined Sewer Overflow regulations could also serve as a driving force.

- Include urban tree canopy in redevelopment models - must incorporate urban forestry (canopy density, ground cover).

- Establish stormwater offset for new development - similar to a regulation in Washington, D.C.

- Concentrate regional growth in urban areas using growth boundaries with fine-scale actions/infill.

- More intelligent Green Infrastructure planning:

- The Watershed Implementation Plan (WIP) has provided this in Delaware

$\circ$ Target to water quality and habitat goals 
- Incorporate more transit options:

○ No expansion of secondary roads (similar to Baltimore County)

○ Use existing infrastructure as a carrot and a stick

$\circ$ Guide future development to priority roads

- Change secondary street requirements to be more connected (no cul de sacs)

- Decreased per capita land-use.

- Increased density in urbanizing areas.

- More countywide focus on designating sensitive areas - zoning does not look at resources. Exclusion - for example, in Pennsylvania, septic is not allowed on any sites with a slope greater than 25 percent. There is more focus on "avoidance" and "mitigation."

- Conservation design will be more widely used.

- Increasing utilization of mixed-use and Transit Oriented Development (TOD).

- More use of sanitary sewers and prioritize growth onto those sewered areas.

- Utilize urban growth boundaries similar to the Urban Rural Demarcation Line established in Baltimore County, Md.

- The TMDL will be more of a driver for linking land-use and water quality in the future. It should help to establish a baseline for all jurisdictions and should use local land-use data and traffic analysis zones (TAZs), when available.

- It continues to be a challenge to correlate land-use policy with water-quality load allocation.

- Accommodate the population increase in already developed areas as well as underutilized sites. In order to assure that new growth goes in those areas, hurdles to redevelopment need to be removed.

- Encourage redevelopment in transit areas.

- Increase density to capacity and increase the density allowed through the use of zoning, tax incentives, and other measures. Implement demonstration projects to help developers, and communities understand the intent.

- Increase access to public transportation.

- Increase mixed-use developments.

- Implement more stormwater practices (urban best management practices).

- Plan for all economic classes - help and educate younger and economically challenged community members to not pollute.

- Increase local green space.

- Decrease impervious cover.

- New development in designated growth areas should be at least 3.5 dwelling units per acre. 
- The last decade was spent on "excluding" areas such as prime farmland and high-quality conservation areas. In the future, "densification" will be increasingly important.

- Amenity attraction will also be important (transit, mixed use, walkable, green space, increased density depending on the area to 4 to 12 dwelling units per acre).

- Focus on redevelopment to accommodate new growth and retrofit untreated stormwater.

- Protective rural zoning yield of greater than 1:20 units per acre.

- Require advanced BMPs for upfront stream buffers, cluster zoning, BMP as a third step, including environmental site design (ESD) and septic improvements.

- Ninety-percent growth in defined urban areas (aspiration).

- Encourage mixed use, TOD, higher density.

- Encourage planning for climate change, adaptation of flood plains and coasts, modeling sea level rise and streamflow.

- Better use of GIS in planning.

\section{What potential policies or strategies could be expected to achieve those changes?}

- Integrate the vast majority of growth within urban areas and add centralized locations within urban growth boundaries.

- Use existing policies, if in place, related to priority funding areas (PFAs), UGBs, or municipal separate storm sewer system (MS4) permitting areas.

○ Establish a group to define urban growth boundaries and priority investment areas.

- Aggregate existing data on urban growth areas, but where localities don't have them, create them for modeling purposes.

- Establish policies related to population size at the urban, suburban, and rural scale.

○ Identify appropriate areas for exclusion from development

○ Hydrologically sensitive areas

$\circ$ Healthy watersheds

○ All land protection priorities (Federal, State, local, and NGO)

$\circ$ Local Green Infrastructure plans

- Make offset programs regional and mitigate for more sensitive areas.

- The general rule for growth and development should be to first avoid impact, then minimize impact, then mitigate.

- Follow up and enforce environmental regulations that are already on the books.

- Planning/zoning authorities identify and facilitate "growth centers" (with regulation, taxes, accommodations, etc.). 
- Regional stormwater management authority and taxation to fund improvements (mitigate impacts on growth).

- Residential designation authority (as per EPA Region 1) - requiring NPDES permits for certain permitting.

- Stronger State planning authority and involvement in lower jurisdiction requirements.

- Provide incentives for urban redevelopment and infill. Remove existing impediments to building in urban areas and streamline the process for builders; for example, streamline permitting process, provide tax breaks, provide infrastructure rather than require developer to provide, and back charge.

- Appropriate Federal stormwater management funds to facilitate retrofitting.

- Amend development ordinances to include requirements for vegetated buffers.

- Establish designated growth areas and enforce them.

- Establish monetary penalties for failing to plan or mitigate water quality impacts of growth.

- Establish urban canopy threshold goals.

- Require no net loss of forest lands.

- Require open space areas in all new development projects.

- Limit expansion of rural roads.

- Give expedited permits for development that will be nutrient neutral.

- Put taxes on units for additional stormwater and (or) nutrients associated with new development.

- Subsidize development that maintains or decreases loadings.

- All development policies (transportation, growth, etc.) at all levels (Federal transportation policy, State permitting policies, county zoning) should explicitly incorporate water quality consideration (similar to the WRE in Maryland).

- Similarly, all levels of governments should develop wastewater management plans.

- Reserve inconsistencies across Federal, State, and local policies on BMPs and codes, for example.

- Assure adequate, long-term funding for infrastructure.

- Update development codes (such as subdivision codes) at the local level in order to promote greener development and reconcile conflicts.

- Tax incentives to developers to build infill, redevelopment, and mixed-use projects and provide density bonuses for such projects.

- Initiate more transfer of development rights (TDR) programs.

- Education of staff and elected officials on how to link land-use policy to water quality is needed. Create a tutorial on how to do what Baltimore County did.

- Determine a funding stream for new strategies.

- Provide density bonuses for mixed use and implement demonstration projects. 
- Utilize tax and other incentives to increase density and allow for more mixed-use developments.

- Encourage community members to be more active in the design of public spaces.

- Better government coordination - impose regional mandates to require jurisdictions to coordinate when development projects have regional implications. (Give priority to joint municipal planning projects.)

- Include all levels of government on local boards to inform master plans.

- Implement shared parking policies to reduce the need for redundant parking and thereby decrease impervious cover (churches and businesses).

- Implement higher standards for stormwater management.

- Augment Agricultural Preservation programs and fund them.

- Build agricultural best management practices (BMPs) into the easement requirements.

- Develop urban BMPs and incentives.

- Regional planning is needed: there is competition between neighboring communities and economic and political impediments to regional planning.

- Fix existing loopholes to get intended zoning in rural areas.

- Target reductions needed and better coordinate with the agricultural sector.

- Provide provisions for transit infrastructure.

- Incentive programs for redevelopment, such as the Maryland Historic Conservation Credit, tax credits, rural preservation, dedicated funding, tax programs. Maryland Agricultural Land Preservation Foundation (MALPF) requires planning at county level to get State money.

- Taxes that help farmers, such as estate tax relief, money to support best management practices.

- Require economic and water analysis of plans to show if viable.

- Better cooperation with counties, municipalities (regional planning), regional planning/governance what would a regional authority do? How much authority would they have? Perhaps a regional water authority.

- Economic and water analysis fix Metropolitan Planning Organization (MPO) issues across State lines.

- Redevelopment: provide incentive for redevelopment projects such as fast tracking paperwork, more flexible regulation with regard to density or use, tax incentive zones.

- There was a question as to whether offsets and Watershed Implementation Plans equalize costs of greenfield and redevelopment.

- Opening up new growth areas and ensuring water supply and treatment roads, schools, amenities, parks - using infrastructure investments.

- Provide funding to convert blighted areas to open space. Governments begin consolidating properties to package for developers to convert to green space (or redevelopment) and banking, direct water benefits. 


\section{Constraints to Changing the Trends in Development}

It was echoed in multiple groups that money and politics continue to strain any changes at the local level.

- There is an unwillingness to believe you can make money with smaller lot sizes.

- There is resistance against higher density and integrated conservation.

- There is a fundamental philosophical challenge in getting developers and financiers to think differently.

- There are border discrepancies between some counties and States with regard to land-use policy, which can lead to problems of 'leakage' - that is, uncoordinated planning across municipalities allows for unfavorable development patterns to move a short distance to adjacent municipalities with lower/different standards.

- Rural counties are attracting demographics who are purposefully staying away from dense communities.

- Jobs-to-housing mix is low and vehicle miles traveled (VMT) is low, and rural areas want to keep it this way.

- Stormwater management technology is not effective. There is a need for better technology. Low impact development (LID) projects are not working, as the maintenance has been poor and the soils in some areas are too poor to support LID.

- Conservation zoning or clustering homes on smaller lots with less impervious area overall is a hard sell for water quality benefits because overall the VMT is still high.

- Transfer of development rights (TDR) programs are currently not economically viable. There are currently too many bonuses on receiving areas and the wastewater capacity cannot accommodate the transferred growth.

- Some jurisdictions feel that conversion of agricultural lands to rural residential is a good move for water quality. 